\title{
GLOBIO3: A Framework to Investigate Options for Reducing Global Terrestrial Biodiversity Loss
}

\author{
Rob Alkemade, ${ }^{1 *}$ Mark van Oorschot, ${ }^{1}$ Lera Miles, ${ }^{2}$ Christian Nellemann, ${ }^{3}$ \\ Michel Bakkenes, ${ }^{1}$ and Ben ten Brink ${ }^{1}$
}

\begin{abstract}
${ }^{1}$ Netherlands Environmental Assessment Agency (PBL), P. O. Box 303, 3720 AH Bilthoven, The Netherlands; ${ }^{2}$ UNEP World Conservation Monitoring Centre, 219 Huntingdon Road, Cambridge CB3 oDL, Cambridgeshire, UK; ${ }^{3}$ UNEP/GRID-Arendal/NINA Fakkelgaarden, Storhove, N-2624 Lillehammer, Norway
\end{abstract}

\begin{abstract}
The GLOBIO3 model has been developed to assess human-induced changes in biodiversity, in the past, present, and future at regional and global scales. The model is built on simple cause-effect relationships between environmental drivers and biodiversity impacts, based on state-of-the-art knowledge. The mean abundance of original species relative to their abundance in undisturbed ecosystems (MSA) is used as the indicator for biodiversity. Changes in drivers are derived from the IMAGE 2.4 model. Drivers considered are landcover change, land-use intensity, fragmentation, climate change, atmospheric nitrogen deposition, and infrastructure development. GLOBIO3 addresses (i) the impacts of environmental drivers on MSA and their relative importance; (ii) expected trends under various future scenarios; and (iii) the likely effects of various policy response options. GLOBIO3 has been used successfully in several integrated regional and global assessments. Three
\end{abstract}

different global-scale policy options have been evaluated on their potential to reduce MSA loss. These options are: climate-change mitigation through expanded use of bio-energy, an increase in plantation forestry, and an increase in protected areas. We conclude that MSA loss is likely to continue during the coming decades. Plantation forestry may help to reduce the rate of loss, whereas climate-change mitigation through the extensive use of bioenergy crops will, in fact, increase this rate of loss. The protection of $20 \%$ of all large ecosystems leads to a small reduction in the rate of loss, provided that protection is effective and that currently degraded protected areas are restored.

Key words: biodiversity; MSA; policy options; climate change; land-use change; fragmentation; nitrogen; infrastructure; forestry; bioenergy; protected areas.

\section{INTRODUCTION}

In recent years, several studies on global biodiversity loss have been carried out. These studies de-

Received 25 April 2008; accepted 23 December 2008; published online 13 February 2009

Author Contributions RA-Writing, study design, data analyses; $\mathrm{MvO}$-Writing, research; LM- Writing, data analyses; $\mathrm{CN}$-Contribution to method; MB-Research, data analyses; BtB-Contribution to method. *Corresponding author; e-mail: rob.alkemade@pbl.nl scribed the biodiversity situations at that time (Hannah and others 1994; Sanderson and others 2002; Wackernagel and others 2002; McKee and others 2003; Cardillo and others 2004; Gaston and others 2003), or used expert opinions to estimate potential future impacts (Sala and others 2000; Petit and others 2001). In the Global Environment Outlook 3 (UNEP 2002a) the consequences of four socio- economic scenarios on biodiversity were as- 
sessed, using the approaches of both the IMAGE Natural Capital Index (NCI) and GLOBIO2 (UNEP/ RIVM 2004). In IMAGE-NCI biodiversity loss, defined as a deviation from the undisturbed pristine situation, was related to increased energy use, land-use change, forestry, and climate change, whereas in GLOBIO2 (UNEP 2001) the human influence on biodiversity was based on relationships between species diversity and the distance to roads and other infrastructure. The Millennium Ecosystem Assessment (MA) used a combination of IMAGE 2.2 (Alcamo and others 1998; IMAGEteam 2001) and Species Area Relationships to predict biodiversity loss, resulting from expected changes in land use, climate change, and nitrogen deposition (MA 2005).

In 2002, during the sixth meeting of the Conference of the Parties to the Convention on Biological Diversity (CBD), the parties committed themselves to achieve, by 2010, a significant reduction in the current rate of biodiversity loss at the global, regional, and national level; as a contribution to poverty alleviation; and to the benefit of all life on earth (UNEP 2002b). Later that year, governments adopted a plan of implementation at the World Summit on Sustainable Development (WSSD) in Johannesburg that recognized the same target and endorsed the CBD as the key instrument for the conservation and sustainable use of biological diversity.

To meet the challenge of evaluating the targets set by CBD and WSSD, an international consortium, made up of the UNEP World Conservation Monitoring Centre (WCMC), UNEP\GRID-Arendal and the Netherlands Environmental Assessment Agency (PBL) has combined the GLOBIO2 and the IMAGE-NCI approach, together with some aspects of the MA approach, into a new Global Biodiversity Model (GLOBIO3).

GLOBIO3 is built on a set of equations linking environmental drivers and biodiversity impact (cause-effect relationships). Cause-effect relationships are derived from available literature using meta-analyses. GLOBIO3 describes biodiversity as the remaining mean species abundance (MSA) of original species, relative to their abundance in pristine or primary vegetation, which are assumed to be not disturbed by human activities for a prolonged period. MSA is similar to the Biodiversity Integrity Index (Majer and Beeston 1996) and the Biodiversity Intactness Index (Scholes and Biggs 2005) and can be considered as a proxy for the CBD indicator on trends in species abundance (UNEP 2004). The main difference between MSA and BII is that every hectare is given equal weight in MSA, whereas BII gives more weight to species rich areas. MSA is also similar to the Living Planet Index (LPI, Loh and others 2005), which compares changes in populations to a 1970 baseline, rather than to primary vegetation. It should be emphasized that MSA does not completely cover the complex biodiversity concept, and complementary indicators should be included, when used in extensive biodiversity assessments (Faith and others 2008). Individual species responses are not modeled in GLOBIO3; MSA represents the average response of the total set of species belonging to an ecosystem. The current version of GLOBIO3 is restricted to the terrestrial part of the globe, excluding Antarctica. The global pictures and figures in this paper, therefore, refer only to terrestrial ecosystems.

Global environmental drivers of biodiversity change are input for GLOBIO3. We selected these drivers from a list based on 10 studies (Table 1). Only direct drivers shown in Table 1 were selected. No cause-effect relationships are available for the drivers 'biotic exchange' and 'atmospheric $\mathrm{CO}_{2}$ concentration' so they are not included in the current version.

The drivers land-use change and harvesting (mainly forestry), atmospheric nitrogen deposition, fragmentation, and climate change are sourced from the Integrated Model to Assess the Global Environment (IMAGE; MNP 2006). Infrastructure development uses the module developed within GLOBIO2 (UNEP 2001).

GLOBIO3 can be used to assess (i) the impacts of environmental drivers on MSA and their relative importance; (ii) expected trends under various future scenarios; and (iii) the likely effects of various responses or policy options. The model is designed to quantitatively compare MSA patterns and changes therein, at the scale of world regions. In this paper, we describe the cause-effect relationships between the environmental drivers and MSA; the aggregation procedures to calculate overall MSA values, and subsequently explore possible options that may reduce MSA loss on a global scale in light of the CBD target, assuming that MSA loss is a good indicator for biodiversity loss.

The options we explored are: (i) a climate change mitigation package, including energy consumption savings and the extensive use of bio-energy (Metz and Van Vuuren 2006); (ii) an increase in plantation forestry, which aims to fully meet the wood demand (Brown 2000); and (iii) a system of protected areas, representing all the world's ecosystems and all endangered and critically endangered species known to be globally confined to single sites (IUCN 2004; sCBD and MNP 2007). We compared 
Table 1. Major Driving Forces or Drivers Used in Large-Scale Studies of Multiple Human Impacts on Natural Systems

\begin{tabular}{|c|c|c|}
\hline Driver & Type $^{a}$ & Reference \\
\hline $\begin{array}{l}\text { Land-use change } \\
\text { (including forestry) }\end{array}$ & $\mathrm{D}$ & $\begin{array}{l}\text { Hannah and others (1994); Sala and others (2000); } \\
\text { Sanderson and others (2002); Wackernagel and others (2002); } \\
\text { Petit and others (2001); UNEP/RIVM (2004); UNEP (2001); } \\
\text { MA (2005); Gaston and others (2003) }\end{array}$ \\
\hline Climate change & $\mathrm{D}$ & $\begin{array}{l}\text { Sala and others (2000); Petit and others (2001); } \\
\text { UNEP/RIVM (2004); MA (2005) }\end{array}$ \\
\hline Atmospheric $\mathrm{N}$ deposition & $\mathrm{D}$ & $\begin{array}{l}\text { Sala and others (2000); Petit and others (2001); } \\
\text { MA (2005) }\end{array}$ \\
\hline Biotic exchange & $\mathrm{D}$ & Sala and others (2000) \\
\hline Atmospheric $\mathrm{CO}_{2}$ concentration & $\mathrm{D}$ & Sala and others (2000) \\
\hline Fragmentation & $\mathrm{D}$ & Wackernagel and others (2002); Sanderson and others (2002) \\
\hline Infrastructure & $\mathrm{D}$ & Wackernagel and others (2002); Sanderson and others (2002); UNEP (2001) \\
\hline Harvesting (including fisheries) & $\mathrm{D}$ & Wackernagel and others (2002) \\
\hline Human population density & I & McKee and others (2003); Cardillo and others (2004); UNEP/RIVM (2004) \\
\hline Energy use & I & UNEP/RIVM (2004) \\
\hline
\end{tabular}

${ }^{a}$ Direct (D) and indirect (I) according to the definition of the conceptual framework of the Millennium Ecosystem Assessment (MA 2003). A direct driver unequivocally influences ecosystem processes and, therefore, its impact can be identified and measured. The main direct drivers are changes in land cover and land use, species introductions and removals, and external inputs. An indirect driver operates more diffusely, often by altering one or more direct drivers. Major indirect drivers include demographic, economic, socio-political and cultural ones, as well as those of science and technology (MA 2003).

the projected effects of these policy options, by 2050 , with the results of a reference scenario that assumes moderate growth of the human population and the economy, and an increased agricultural productivity (OECD 2008). The effects of the socio-economic developments in the reference scenario and the policy options on land-use change and climate change were calculated with the IMAGE 2.4 model (MNP 2006). MSA values at a global level and for nine world regions (Figure 1) were calculated with GLOBIO3.

\section{MethodS}

\section{Meta-Analyses and Cause-Effect Relationships}

To construct cause-effect relationships for each driver we conducted meta-analyses of peer-reviewed literature. Meta-analysis is the quantitative synthesis, analysis, and summary of a collection of studies and requires that the results be summarized in an estimate of the 'effect size' (Osenberg and others 1999). MSA is considered to be the effect size in our analyses. Meta-analyses were performed by first scanning the peer-reviewed literature using a relevant search profile in tools, such as the SCI-Web of Science. Secondly, we selected papers that present data on species composition in disturbed and undisturbed situations. Thirdly, these data were extracted from the paper and MSA values and their variances were calculated. MSA val- ues were calculated for each study by first dividing the abundance of each species, recorded as density, numbers, or relative cover, found in disturbed situations by its abundance found in undisturbed situations, then truncate these values at 1 , and finally calculate the mean over all species considered in that study. Species not found in undisturbed vegetations were omitted. Finally, a statistical analysis was carried out by using S-PLUS 7.1 (Insightful Corp 2005).

To find relevant papers for land use, land-use intensity, and harvesting (including forestry), SCI-Web of Science was queried in April 2008 using the key words species diversity, biodiversity, richness, or abundance; land use, or habitat conversion; and pristine, primary, undisturbed, or original. The land-use types were categorized into 10 classes: primary vegetation, lightly used forests, secondary forests, forest plantations, livestock grazing, manmade pastures, agroforestry, low-input agriculture, intensive agriculture, and built-up areas (Table 2). A linear mixed effect model was fitted to the data (Venables and Ripley 1999).

The analysis for $\mathrm{N}$ deposition in excess of critical loads (N exceedance) was based on data from empirical $\mathrm{N}$ critical-load studies (Bobbink and others 2003). Additional data were obtained from SCI-Web of Science queries in 2007. Data were analyzed for separate biomes using linear or loglinear regression.

In addition to papers collected for GLOBIO2 (UNEP 2001), Scopus and Omega (Utrecht Uni- 


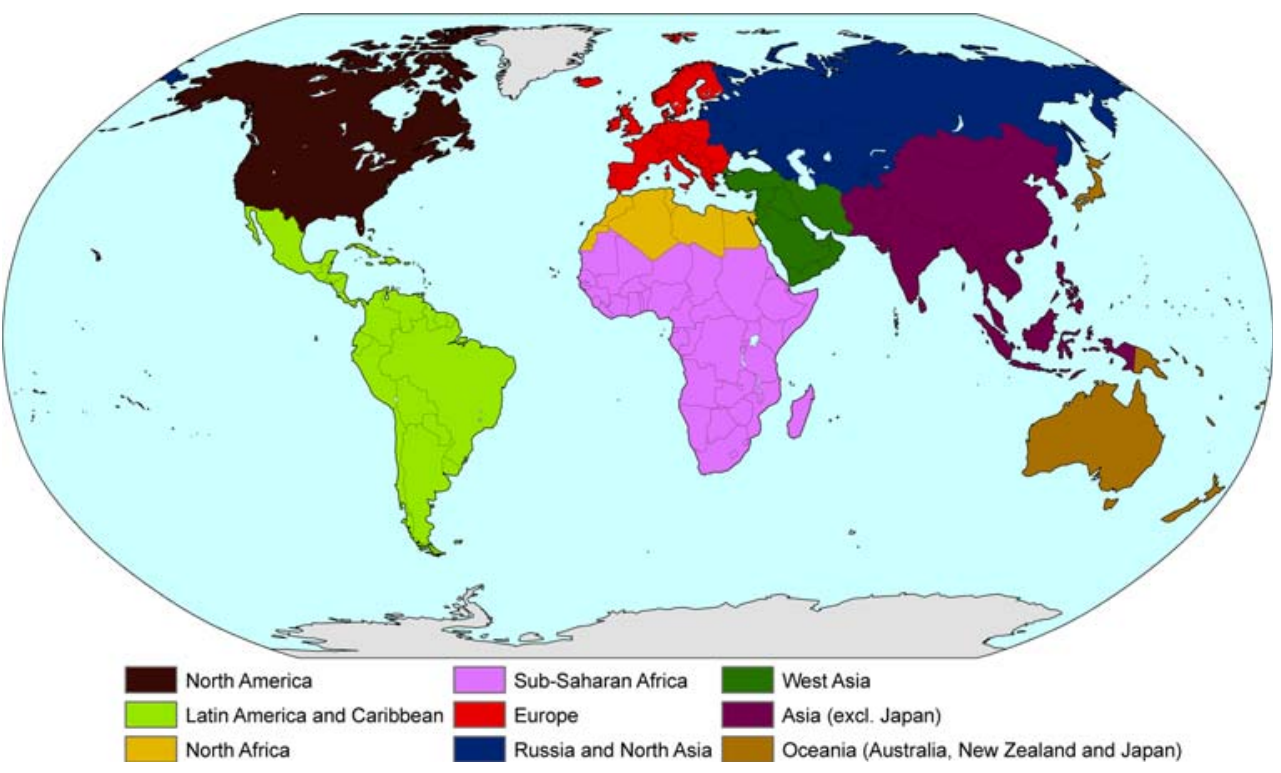

Figure 1. The regions considered: Greenland and Antarctica are excluded from the analysis.

Table 2. Proportions (\%) of Low-Input and Intensively Used Agricultural Land for Selected World Regions, Based on Farming System Descriptions (Dixon and others 2001) and GLC2000

\begin{tabular}{lllr}
\hline Region & $\begin{array}{l}\text { Intensive } \\
\text { agriculture }\end{array}$ & $\begin{array}{l}\text { Low-input } \\
\text { agriculture }\end{array}$ & $\begin{array}{l}\text { Total } \\
\left({ }^{*} \mathbf{1 0 0 0} \mathbf{k m}^{2}\right)\end{array}$ \\
\hline West Asia and North Africa & 64 & 36 & 852 \\
Sub-Saharan Africa & 24 & 76 & 1632 \\
Russia and North Asia & 42 & 58 & 2738 \\
Latin America & 73 & 27 & 1576 \\
South Asia & 57 & 43 & 2141 \\
East Asia & 93 & 7 & 2356 \\
\hline
\end{tabular}

versity Digital Publications Search Machine) were queried using the key words: road impact, infrastructure development, road effect, road disturbance, and road avoidance in August 2008. For each impact zone derived from UNEP/RIVM (2004) we estimated MSA using generalized linear mixed models (Pinheiro and Bates 2000). The impact zones include effects of disturbance on wildlife, increased hunting activities, and small-scale land-use change along roads.

The relationship between MSA and patch size was built upon data on the minimum area requirement of animal species defined as the area needed to support at least a minimum viable population (Verboom and others 2007). The proportion of species for which a certain area is sufficient for their MVP is calculated and considered a proxy for MSA. A linear mixed effect model was fitted to the data (Venables and Ripley 1999).

The cause-effect relationships for climate change are based on model studies. Species Distribution Models from the EUROMOVE model (Bakkenes and others 2002) were used to estimate species distributions for the situation in 1995 and the forecasted situation in 2050 for three different climate scenarios. For each grid cell the proportion of remaining species were calculated by comparing the species distribution maps for 1995 and for 2050 (Bakkenes and others 2006). For each biome, a linear regression equation was estimated between the proportion of remaining species and the global mean temperature increase (relative to pre-industrial) (GMTI), corresponding to the different climate scenarios. Additionally, the expected stable area for each biome calculated for different GMTIs was derived from Leemans and Eickhout (2004). They presented percentages of stable area of biomes at $1,2,3$, and $4^{\circ} \mathrm{C}$ GMTI. Linear regression analysis was used to relate the percentages and GMTI. Stable areas for each biome (IMAGE), or group of plant species occurring within a biome (EUROMOVE) are considered proxies for MSA.

\section{Input Data}

The data for land cover and/or land use-and changes therein-come from the IMAGE model at 
Table 3. Proportions (\%) of Forest-Use Classes Derived from FAO (2001) and GLC2000 for Different World Regions

\begin{tabular}{llcrr}
\hline World region & $\begin{array}{l}\text { Primary } \\
\text { forest }\end{array}$ & $\begin{array}{l}\text { Secondary } \\
\text { forest }\end{array}$ & $\begin{array}{l}\text { Forest } \\
\text { plantation }\end{array}$ & $\begin{array}{l}\text { Total area } \\
\left({ }^{*} \mathbf{1 0 0 0} \mathbf{k m}^{2}\right)\end{array}$ \\
\hline North America & 55 & 43 & 2 & 8292 \\
Latin America & 84 & 15 & 1 & 9432 \\
North Africa & 31 & 31 & 38 & 45 \\
Sub-Saharan Africa & 94 & 5 & 1 & 8741 \\
Europe & 59 & 36 & 5 & 924 \\
Russia and North Asia & 91 & 76 & 2 & 145 \\
West Asia & 31 & 14 & 33 & 5126 \\
South and East Asia & 67 & 11 & 8 & 1737 \\
Oceania and Japan & 81 & 17 & 5 & 42925 \\
Total & 78 & & &
\end{tabular}

The proportion of lightly used forest could not be estimated and is included in the primary forest category.

a 0.5 by $0.5^{\circ}$ resolution. To increase the spatial detail within each IMAGE grid cell, we calculated the proportion of each type of land cover and/or land use from the Global Land Cover 2000 (GLC2000) map, representing the year 2000 (Bartholome and others 2004). GLC2000 distinguishes 10 forest classes, 5 classes of low vegetation (grasslands and scrublands), 3 cultivated land classes, ice and snow, bare areas and artificial surfaces (Bartholome and others 2004). To translate these classes to the land-use categories considered here we first aggregated the GLC2000 classes into broader land-cover classes (Table 4). Secondly we assigned different land-use intensity classes to these broad classes. 'Cultivated and managed areas' was divided into 'intensive agriculture' and 'low input agriculture' based on estimates of the distribution of intensive and low-input agriculture in different regions of the world, from Dixon and others (2001). We assumed $100 \%$ intensive agriculture in regions not covered by these estimates (Table 2). 'Mosaic of cropland and forest,' was treated as a 50$50 \%$ mixture of 'low input agriculture' and 'lightly used forest'.

'Scrublands and grasslands' were divided into 'pristine vegetations,' 'livestock grazing areas,' and 'man-made pastures'. 'Livestock grazing areas' were estimated by IMAGE for current and future years and distributed, proportionally, to all GLC2000 classes containing low vegetation. 'Manmade pastures' were assigned to the GLC2000 class of 'herbaceous cover' if found in originally forested areas according to the potential vegetation map generated by IMAGE (based on the BIOME model, Prentice and others 1992). For future scenarios, the change in agricultural land and grazing areas calculated by IMAGE for each world region, was added to current land use and, proportionally, distributed over all grid cells.

Similarly, we assigned the land-use categories 'lightly used forest,' 'secondary forest,' and 'forest plantations' to forest classes of GLC2000. We used national data on forest use from FAO (2001) and assigned the derived fractions for each region, proportionally, to all grid cells that contain one or more GLC2000 forest classes (Table 3). For future scenarios, we used calculations of future timber demands to obtain the areas needed to produce the timber, and proportionally distributed the new fraction to each grid cell.

Water bodies are excluded from the analyses and 'artificial surfaces' are all considered to be built-up areas. Bare areas are considered to be areas of primary vegetation if the potential vegetation is ice, snow, tundra, or desert, according to the BIOME model. Scrub classes are considered to be secondary vegetation if the potential vegetation is forest, except for boreal forests, where scrub vegetation is assumed to be part of the natural ecosystem.

IMAGE simulates global atmospheric N deposition, based on data on agricultural and live stock production (MNP 2006). A critical-load map for major ecosystems was derived from the soil map of the world and from the sensitivity of ecosystems to $\mathrm{N}$ inputs (Bouwman and others 2002). The exceedance of $\mathrm{N}$ deposition was defined to be the amount of $\mathrm{N}$ in excess of the critical load and obtained by subtracting the critical load from $\mathrm{N}$ deposition. The N-exceedance is input for GLOBIO3.

A global map of linear infrastructure, containing roads, railroads, power lines, and pipe lines, was derived from the Digital Chart of the World (DCW) database (DMA 1992). Buffers of different width, 
Table 4. Relation Between GLC2000 Classes and Land-Use Categories Used in GLOBIO3, Including Corresponding $\mathrm{MSA}_{\mathrm{LU}}$ Values

\begin{tabular}{|c|c|c|c|c|}
\hline 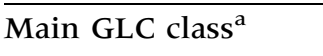 & Sub-category & Description & $\mathrm{MSA}_{\mathrm{LU}}$ & SE \\
\hline Snow and ice $(20)$ & Primary vegetation & $\begin{array}{l}\text { Areas permanently covered with snow or ice } \\
\text { considered as undisturbed areas }\end{array}$ & 1.0 & $<0.01$ \\
\hline Bare areas (19) & Primary vegetation & $\begin{array}{l}\text { Areas permanently without vegetation (for } \\
\text { example, deserts, high alpine areas) }\end{array}$ & 1.0 & $<0.01$ \\
\hline \multirow[t]{4}{*}{$\begin{array}{l}\text { Forests }(1,2,3,4,5,6 \text {, } \\
\quad 7,8,9,10)\end{array}$} & $\begin{array}{l}\text { Primary vegetation } \\
\text { (forest) }\end{array}$ & $\begin{array}{l}\text { Minimal disturbance, where flora and fauna } \\
\text { species abundance are near pristine }\end{array}$ & 1.0 & $<0.01$ \\
\hline & $\begin{array}{l}\text { Lightly used natural } \\
\text { forest }\end{array}$ & $\begin{array}{l}\text { Forests with extractive use and associated dis- } \\
\text { turbance like hunting and selective logging, } \\
\text { where timber extraction is followed by a long } \\
\text { period of re-growth with naturally occurring } \\
\text { tree species }\end{array}$ & 0.7 & 0.07 \\
\hline & Secondary forests & $\begin{array}{l}\text { Areas originally covered with forest or wood- } \\
\text { lands, where vegetation has been removed, } \\
\text { forest is re-growing or has a different cover } \\
\text { and is no longer in use }\end{array}$ & 0.5 & 0.03 \\
\hline & Forest plantation & Planted forest often with exotic species & 0.2 & 0.04 \\
\hline \multirow{3}{*}{$\begin{array}{l}\text { Scrublands and grass- } \\
\text { lands }(11,12,13 \\
14,15)\end{array}$} & $\begin{array}{l}\text { Primary vegetation } \\
\quad \text { (grass- or scrublands) }\end{array}$ & $\begin{array}{l}\text { Grassland or scrubland-dominated vegetation } \\
\text { (for example, steppe, tundra, or savannah) }\end{array}$ & 1.0 & $<0.01$ \\
\hline & Livestock grazing & $\begin{array}{l}\text { Grasslands where wildlife is replaced by grazing } \\
\text { livestock }\end{array}$ & 0.7 & 0.05 \\
\hline & Man-made pastures & $\begin{array}{l}\text { Forests and woodlands that have been con- } \\
\text { verted to grasslands for livestock grazing. }\end{array}$ & 0.1 & 0.07 \\
\hline $\begin{array}{l}\text { Mosaic: cropland/for- } \\
\text { est (17) }\end{array}$ & Agroforestry & $\begin{array}{l}\text { Agricultural production intercropped with } \\
\text { (native) trees. Trees are kept for shade } \\
\text { or as wind shelter }\end{array}$ & 0.5 & 0.06 \\
\hline \multirow[t]{2}{*}{$\begin{array}{l}\text { Cultivated and man- } \\
\text { aged areas }(16,18)\end{array}$} & Low-input agriculture & $\begin{array}{l}\text { Subsistence and traditional farming, extensive } \\
\text { farming, and low external input agriculture }\end{array}$ & 0.3 & 0.12 \\
\hline & Intensive agriculture & $\begin{array}{l}\text { High external input agriculture, conventional } \\
\text { agriculture, mostly with a degree of regional } \\
\text { specialization, irrigation-based agriculture, } \\
\text { drainage-based agriculture. }\end{array}$ & 0.1 & 0.08 \\
\hline Artificial surfaces (21) & Built-up areas & Areas more than $80 \%$ built up & $0.05^{\mathrm{b}}$ & \\
\hline \multicolumn{5}{|c|}{ 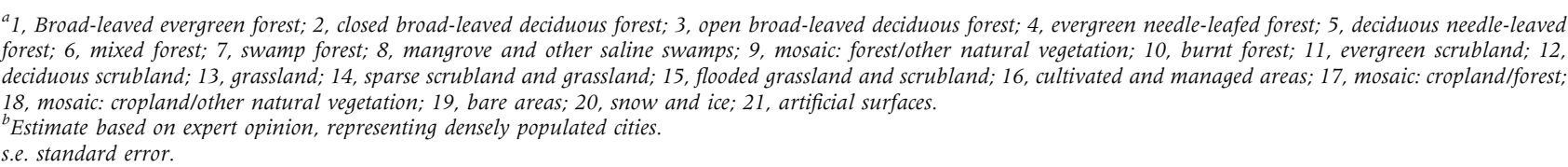 } \\
\hline
\end{tabular}

varying between biomes, were calculated and assigned to impact zones according to UNEP/RIVM (2004). The impact zones were summarized at $0.5^{\circ}$ grid resolution.

Patch sizes were calculated by first reclassifying GLC2000 into two classes: man-made land (including croplands and urban areas) and natural land, all the rest. An overlay with the main roads derived from the infrastructural map resulted in a map of patches of natural areas. For future scenarios, the patch sizes were adapted as a result of land-use change, by adding or subtracting the amount of natural area assigned to each grid cell.
Global mean temperature change was directly derived from IMAGE.

\section{Calculation of MSA and Relative Contributions of Each Driver}

For each driver $X$ a MSA $_{X}$ map is calculated by applying the cause-effect relationships to the appropriate input map. Little quantitative information exists on the interaction between drivers. To assess possible interactions assumptions can be made, ranging from 'complete interaction' (only the worst impact is allocated to each grid cell) to 'no interaction' (the impacts of each driver are cumu- 
lative). In the no-interaction case, for each IMAGE grid cell, GLOBIO3 calculates the overall $\mathrm{MSA}_{i}$ value by multiplying the individual $\mathrm{MSA}_{X}$ maps derived from the relationships for each driver:

$\mathrm{MSA}_{i}=\mathrm{MSA}_{\mathrm{LU}_{i}} * \mathrm{MSA}_{\mathrm{N}_{i}} * \mathrm{MSA}_{\mathrm{I}_{i}} * \mathrm{MSA}_{\mathrm{F}_{i}} * \mathrm{MSACC}_{i}$

where $i$ is a grid cell, $\mathrm{MSA}_{i}$ is the overall value for grid cell $i, \mathrm{MSA}_{X i}$ is the relative mean species abundance corresponding to the drivers LU (land cover/land use), $\mathrm{N}$ (atmospheric $\mathrm{N}$ deposition), I (infrastructural development), F (fragmentation), and CC (climate change).

As the area of land within each IMAGE grid cell is not equal, the $\mathrm{MSA}_{r}$ of a region is the area weighted mean of $\mathrm{MSA}_{i}$ values of all relevant grid cells.

$$
\mathrm{MSA}_{r}=\sum_{i} \mathrm{MSA}_{i} * A_{i} / \sum_{i} A_{i}
$$

where $A_{i}$ is the land area of grid cell $i$.

The relative contribution of each driver to a loss in MSA may be calculated from formulas 1 and 2 .

We assumed that $\mathrm{N}$ deposition does not affect MSA in croplands, because the addition of $\mathrm{N}$ in agricultural systems was expected to be much higher than the atmospheric $\mathrm{N}$ deposition, and should have already been accounted for in the estimation of agricultural impacts. Furthermore, climate change and infrastructure were assumed to affect only natural and semi-natural areas, and effects of infrastructure were reduced in protected areas.

\section{Scenario and Policy Options}

\section{Reference Scenario}

A moderate socio-economic reference scenario has been used as a reference to evaluate the effects of the options (OECD 2008). The key indirect drivers, such as global population and economic activity, increase under this scenario. Between 2000 and 2050 , the global population is projected to grow by $50 \%$ and the global economy to quadruple. This reference scenario is comparable with the B2 scenario in the Special Report on Emissions Scenarios (SRES) (Nakicenovic and others 2000) and the 'Adaptive Mosaic' scenario of the Millennium Ecosystem Assessment (MA 2005).

\section{Option: Climate Change Mitigation Through Energy Policy}

The implementation of an ambitious and bioenergy-intensive climate change mitigation policy option would require substantial changes in the world energy system (Metz and Van Vuuren 2006). The mitigation option studied here involves stabilizing $\mathrm{CO}_{2}$-equivalent concentrations at a level of 450 ppmv, which is in line with keeping the global temperature increase below $2^{\circ} \mathrm{C}$. One of the more promising possibilities for reducing emissions (in particular, from transport and electric power generation) is the use of bioenergy. A scenario has been explored in which bioenergy plays an important role in reducing emissions. In this scenario, major energy-consumption savings are achieved, and $23 \%$ of the remaining global energy supply, in 2050, will be produced from bioenergy.

\section{Option: Plantation Forests}

The demand for wood is expected to increase by $30 \%$, by 2050 , leading to an increased use of (semi-) natural forests under the reference scenario. The option comprises a gradual shift of wood production toward sustainable managed plantations, aiming for a complete supply by plantations by 2050 .

\section{Option: Protected Areas}

Protecting $10 \%$ of all biomes, a target of the CBD Programme of Work on Protected Areas, has nearly been achieved in the baseline scenario. Therefore, we analyzed the implementation of effectively conserving $20 \%$ of all biomes and all known single-site endemics. Conceptual maps of an extended protected-areas network were developed by using the October 2005 version of the World Database of Protected Areas (UNEP/WCMC 2005), the WWF terrestrial biome map (14 categories; Olson and others 2001), and a set of existing prioritization schemes (WWF global 200 terrestrial and freshwater priority ecoregions, Olson and Dinerstein 1998; amphibian diversity areas, Duellman 1999; endemic bird areas, Stattersfield and others 1998; and conservation international hotspots, Myers and others 2000). All sites of alliance for zero extinction (singlesite endemics, Ricketts and others 2005) were selected for addition to the network. To achieve the $20 \%$ target for each biome, based on a consensual view on biodiversity value, potential new, protected cells were ranked for inclusion, based on the number of prioritization schemes that included that cell, with random selection in the case of a tie.

\section{Results}

\section{Cause-Effect Relationships}

\section{Land Use, Harvesting, and Land-Use Intensity}

We identified 89 published data sets, comparing species' abundance between at least one land-use 


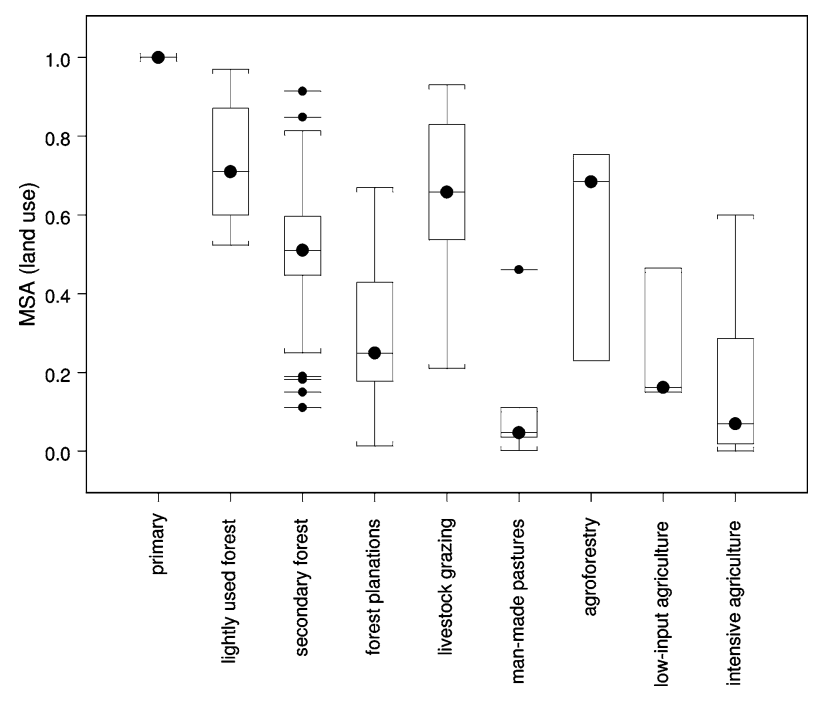

Figure 2. Box and whisker plot of MSA values for each land-use category.

type and primary vegetation. Many studies describe plant or animal species in the tropical forest biome. However, available studies from other biomes confirm the general picture. The estimated MSA values for each land-use category, presented in Table 4 and Figure 2, are significantly different from primary vegetation, but some categories show a high variability, especially secondary forests. For urban areas no proper data were found and the value 0.05 was assigned by expert opinion, representing the densely populated areas of city centers. The analysis will be published in more detail in a paper in preparation.

\section{Atmospheric Nitrogen Deposition}

We found 22 papers on the experimental addition of nitrogen $(\mathrm{N})$ to natural systems and its effects on species richness and species diversity. Cause-effect relationships were established between the yearly amount of added $\mathrm{N}$ which exceeds the empirical critical-load level and the relative local species richness (considered as a proxy for MSA). We as-

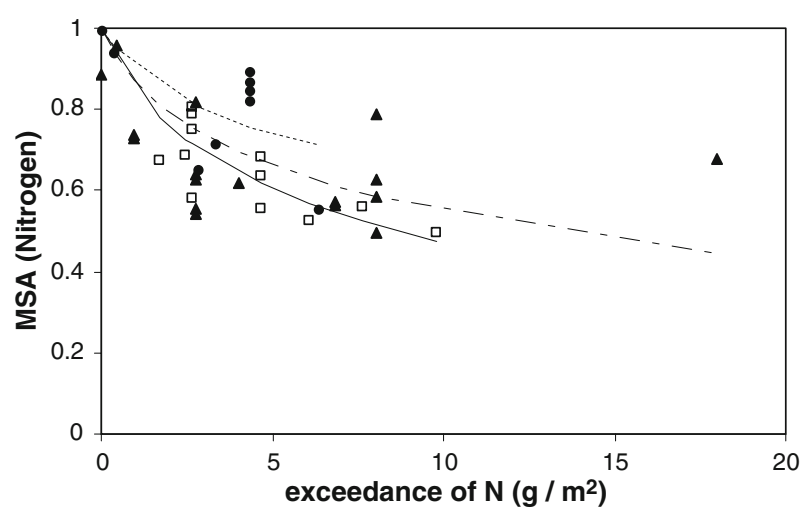

Figure 3. MSA values and regression lines for nitrogen exceedance. Each dot represents a data point from a single study for grasslands $(\boldsymbol{\Delta})$, forests $(\square)$, and Arctic (O).

sumed that the experimental addition of $\mathrm{N}$ has effects that are similar to atmospheric deposition. Table 5 and Figure 3 present the regression equations for the biomes included (more details will be published in a paper in preparation).

\section{Infrastructure}

We used about 74 studies on the impacts of infrastructure on abundances of species. Species groups include birds, mammals, insects, and plants. Some authors studied direct effects of roads and road construction by measuring the abundance of species near roads and on larger distances from roads. Other authors studied indirect effects like the increase of hunting and tourism occurring after road construction. Impacts of infrastructure differ among ecosystems. We derived the impact zones along roads from the UNEP (2001), shown in Figure 4. Table 6 and Figure 5 show the average MSA values for different impact zones using both indirect and direct effects. Indirect effects especially are still noticeable at distances of more than a few kilometers, dependent on biome. We are preparing a paper describing direct and indirect effects, separately, and in more detail.

Table 5. Regression Equations for the Relation Between $\mathrm{N}$ Exceedance $\left(\mathrm{NE}\right.$ in $\mathrm{g} \mathrm{m}^{-2}$ ) and $\mathrm{MSA}_{\mathrm{N}}$ for Three Ecosystems

\begin{tabular}{llllll}
\hline Ecosystem & Equation & $R^{2}$ & $P$ & $n$ & $\begin{array}{l}\text { Applied to GLC2000 } \\
\text { classes (see Table 4) }\end{array}$ \\
& & & & & \\
\hline Arctic alpine ecosystem & $\mathrm{MSA}_{\mathrm{N}}=1-0.15 \ln (\mathrm{NE}+1)$ & 0.81 & $<0.01$ & 9 & Snow and Ice $(20)$ \\
Boreal and temperate forests & $\mathrm{MSA}_{\mathrm{N}}=1-0.22 \ln (\mathrm{NE}+1)$ & 0.96 & $<0.01$ & 12 & Forests $(1,2,3,4,5,6,7,8,9,10)$ \\
Grasslands & $\mathrm{MSA}_{\mathrm{N}}=1-0.19 \ln (\mathrm{NE}+1)$ & 0.85 & $<0.01$ & 21 & Grassland and scrubland
\end{tabular}

$(11,12,13,14,15)$ 


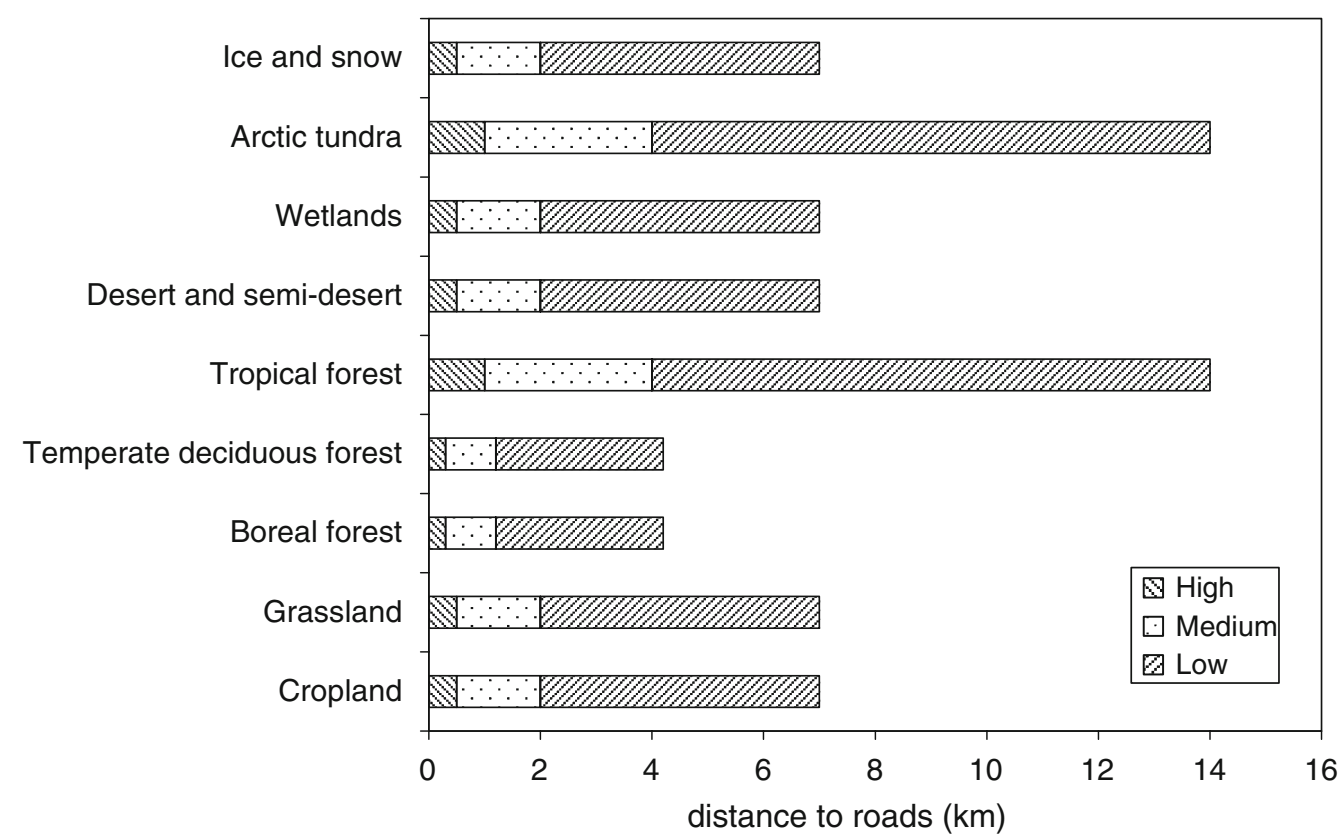

Figure 4. High, medium, and low impact buffer zones (in km) along roads derived from UNEP/RIVM (2004).

Table 6. Impact Buffer Zones (in $\mathrm{km}$ ) Along Roads Derived from UNEP/RIVM (2004) and Corresponding $\left(\mathrm{MSA}_{\mathrm{I}}\right)$ Values

\begin{tabular}{lll}
\hline Impact zone & MSA $_{\text {I }}$ & Standard error \\
\hline High impact & 0.4 & 0.22 \\
Medium impact & 0.8 & 0.13 \\
Low impact & 0.9 & 0.06 \\
No impact & 1.0 & 0.02 \\
\hline
\end{tabular}

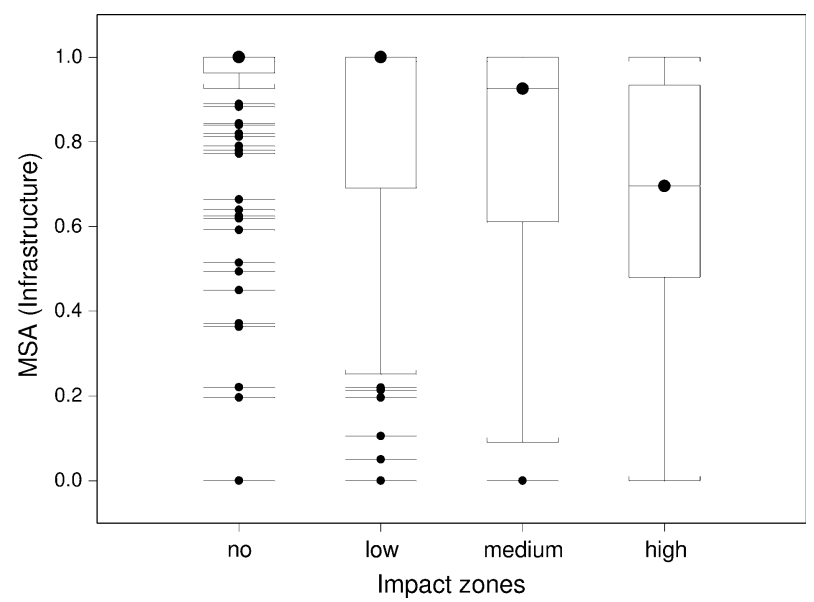

Figure 5. Box and whisker plot of the MSA values for the impact zones along roads.

\section{Fragmentation}

Six datasets on a large sample of species were used to derive the relationship between MSA and patch size,
Table 7. The Relationship Between Area and Corresponding Fraction of Species Assumed to Meet Their Minimal Area Requirement

\begin{tabular}{lll}
\hline Area $\left(\mathrm{km}^{2}\right)$ & MSA $_{\mathrm{F}}$ & SE \\
\hline$<1$ & 0.3 & 0.15 \\
$<10$ & 0.6 & 0.19 \\
$<100$ & 0.7 & 0.19 \\
$<1,000$ & 0.9 & 0.20 \\
$<10,000$ & 0.95 & 0.20 \\
$>10,000$ & 1.0 & 0.20 \\
& & \\
This value is interpreted as the $\mathrm{MSA}_{F}$ value. &
\end{tabular}

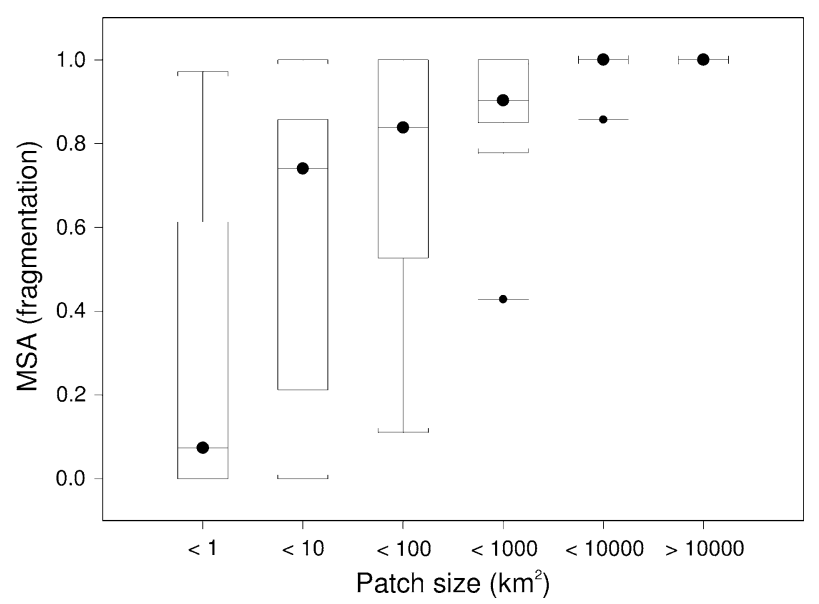

Figure 6. Box and whisker plot of MSA values for different patch size categories. 
using the proportion of species that have a viable population as a proxy (Allen and others 2001; Bouwma and others 2002; Woodroffe and Ginsberg 1998). Table 7 and Figure 6 show MSA values for different patch-size intervals. Data show that patches of over $10,000 \mathrm{~km}^{2}$ of suitable habitat provide sufficient space for viable populations of any species.

\section{Climate Change}

Table 8 shows the regression coefficients for each biome, using either species shifts derived from EUROMOVE or biome shifts from IMAGE. Standard errors of the coefficients shown, only describe the uncertainty of the regression model and not of the underlying data and models. In GLOBIO3, we selected the regression-equation lines that predict the smallest effects, yielding conservative estimates. Figure 7 shows some results of the EUROMOVE analysis.

\section{Application: Exploring Options to Reduce Biodiversity Loss}

\section{Reference Scenario}

Globally, the need for food, fodder, energy, wood, and infrastructure will unavoidably lead to a decrease in undisturbed areas within all ecosystems. The impacts of climate change, nitrogen deposition, fragmentation, and infrastructure on biodiversity will further expand. As a result, global MSA is projected to decrease from about 0.70 in 2000 , to about 0.63 by 2050 . To put these figures

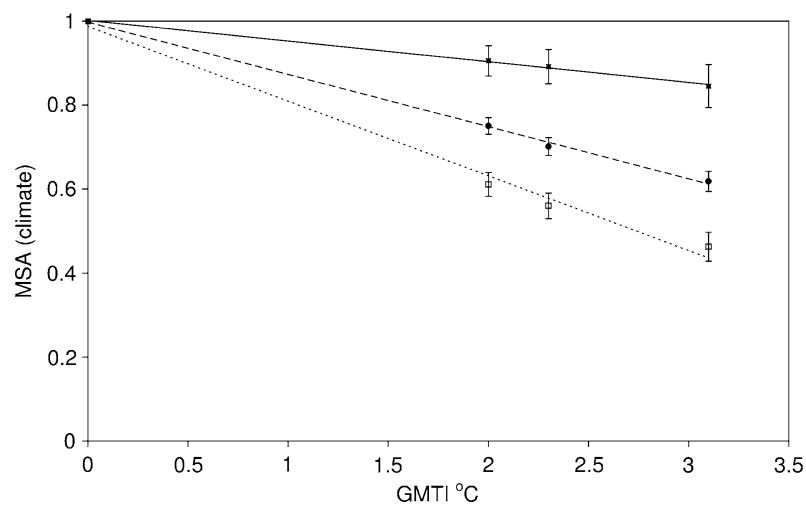

Figure 7. Some results of regression lines relating estimated MSA values with global mean temperature increase $\left({ }^{\circ} \mathrm{C}\right)$ for tundra $(\square)$, temperate mixed forests $(\square)$, and grasslands $(\mathbf{)})$. The error bars reflect only the standard error derived from the regression analysis.

in context, 0.01 of global MSA is equivalent to the conversion of 1.3 million $\mathrm{km}^{2}$ (an area the size of Peru or Chad) of intact primary ecosystems to completely transformed areas with no original species remaining.

Figure 8A and B shows the global MSA map for 2000 and for the baseline scenario in 2050, respectively. Land-use effects are dominant in these maps. Dryland ecosystems—grasslands and savanna-will be particularly vulnerable to conversion, over the next 50 years. Increasing effects of infrastructure are visible in northern Asia and Africa. Much of the world's remaining natural areas will consist of mountainous, boreal, tundra, ice, and arid to semi-

Table 8. Slopes $b$ in the Regression Equations MSA $_{\mathrm{CC}}=1-b^{*}$ GMTI Between MSA and Global Mean Temperature Increase, Calculated with IMAGE and EUROMOVE

\begin{tabular}{|c|c|c|c|c|c|c|}
\hline \multirow[t]{2}{*}{ BIOME } & \multicolumn{3}{|c|}{ IMAGE } & \multicolumn{3}{|c|}{ EUROMOVE } \\
\hline & $b$ & SE & $P$ & $b$ & SE & $P$ \\
\hline Ice & $0.02 *$ & 0.024 & n.s. & 0.07 & 0.011 & $<0.01$ \\
\hline Tundra & 0.17 & 0.028 & $<0.01$ & $0.05^{*}$ & 0.019 & $<0.05$ \\
\hline Wooded tundra & 0.24 & 0.030 & $<0.01$ & $0.07^{*}$ & 0.018 & $<0.01$ \\
\hline Boreal forest & $0.04 *$ & 0.074 & n.s. & 0.07 & 0.018 & $<0.01$ \\
\hline Cool conifer forest & 0.17 & 0.029 & $<0.01$ & $0.08^{*}$ & 0.016 & $<0.01$ \\
\hline Temp. mixed forest & $0.04^{*}$ & 0.037 & n.s. & 0.12 & 0.016 & $<0.01$ \\
\hline Temp. deciduous forest & $0.09^{*}$ & 0.032 & $<0.05$ & 0.14 & 0.015 & $<0.01$ \\
\hline Warm mixed forest & $0.05^{*}$ & 0.065 & n.s. & 0.17 & 0.015 & $<0.01$ \\
\hline Grassland and steppe & $0.09^{*}$ & 0.037 & 0.07 & 0.17 & 0.015 & $<0.01$ \\
\hline Hot dessert & $0.04^{*}$ & 0.040 & n.s. & - & & \\
\hline Scrubland & $0.12^{*}$ & 0.030 & $<0.01$ & 0.17 & 0.014 & $<0.01$ \\
\hline Savanna & $0.09 *$ & 0.049 & n.s. & - & & \\
\hline Tropical woodland & $0.03 *$ & 0.057 & n.s. & - & & \\
\hline Tropical forest & $0.03 *$ & 0.031 & n.s. & - & & \\
\hline
\end{tabular}




\section{0}

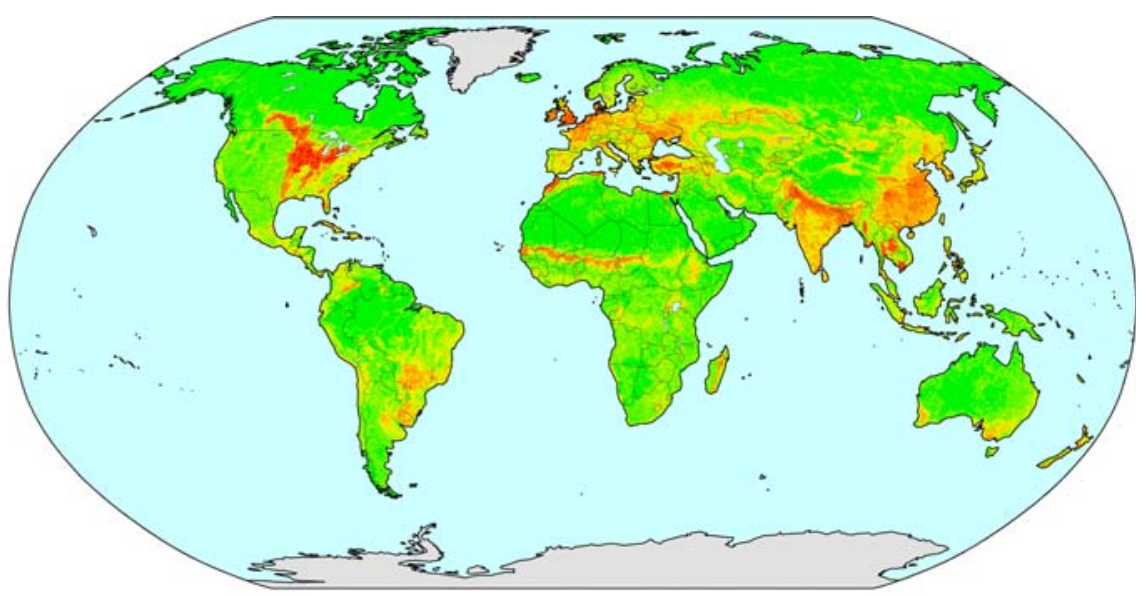

2050

MSA
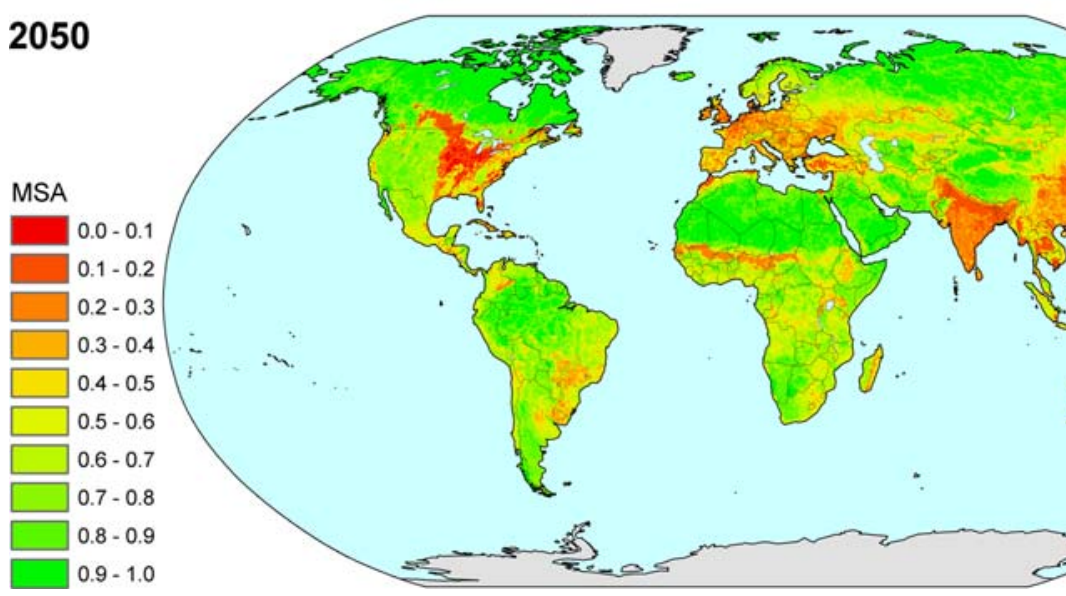

Figure 8. Combined relative mean species abundance of original species (MSA), using all pressure factors. (A) year 2000, and (B) reference scenario for 2050.

Table 9. Overview of $\mathrm{MSA}_{r}$ Values for Each Region and Global Averages for 2000 and 2050 According to the Reference Scenario

\begin{tabular}{|c|c|c|c|c|c|}
\hline Region & 2000 & $\begin{array}{l}\text { Reference } \\
2050\end{array}$ & $\begin{array}{l}\text { Climate } \\
\text { change }\end{array}$ & $\begin{array}{l}\text { Plantation } \\
\text { forestry }\end{array}$ & $\begin{array}{l}\text { Protected } \\
\text { areas }\end{array}$ \\
\hline North America & 0.75 & 0.65 & -0.015 & -0.003 & +0.01 \\
\hline Latin America & 0.66 & 0.59 & -0.016 & 0 & +0.005 \\
\hline North Africa & 0.87 & 0.84 & 0.006 & 0 & +0.002 \\
\hline Sub-Saharan Africa & 0.73 & 0.61 & -0.017 & 0.004 & +0.008 \\
\hline Europe & 0.45 & 0.33 & -0.002 & -0.006 & +0.011 \\
\hline Russia and North Asia & 0.76 & 0.71 & -0.02 & -0.004 & +0.012 \\
\hline West Asia & 0.76 & 0.72 & 0.002 & 0 & +0.016 \\
\hline South and East Asia & 0.55 & 0.46 & 0.004 & +0.008 & +0.013 \\
\hline Oceania and Japan & 0.78 & 0.74 & -0.006 & 0 & +0.029 \\
\hline World & 0.70 & 0.63 & -0.01 & +0.001 & +0.011 \\
\hline
\end{tabular}

For each option additional (-) or avoided (+) loss in 2050, relative to the reference scenario.

arid ecosystems, all of which are generally considered less suitable for human settlement.

Regional and global averages of MSA and the relative contributions of the different drivers to MSA loss in 2000 are shown in Table 9 and Figure 9. Here, land uses, including agriculture and forestry, are the most important factors of reducing MSA. Infrastructure and fragmentation are smaller factors, but still important, whereas climate change and $\mathrm{N}$ deposition are shown to be minor factors in 2000. Over time, the relative importance of the drivers will change; the effect of climate change is 


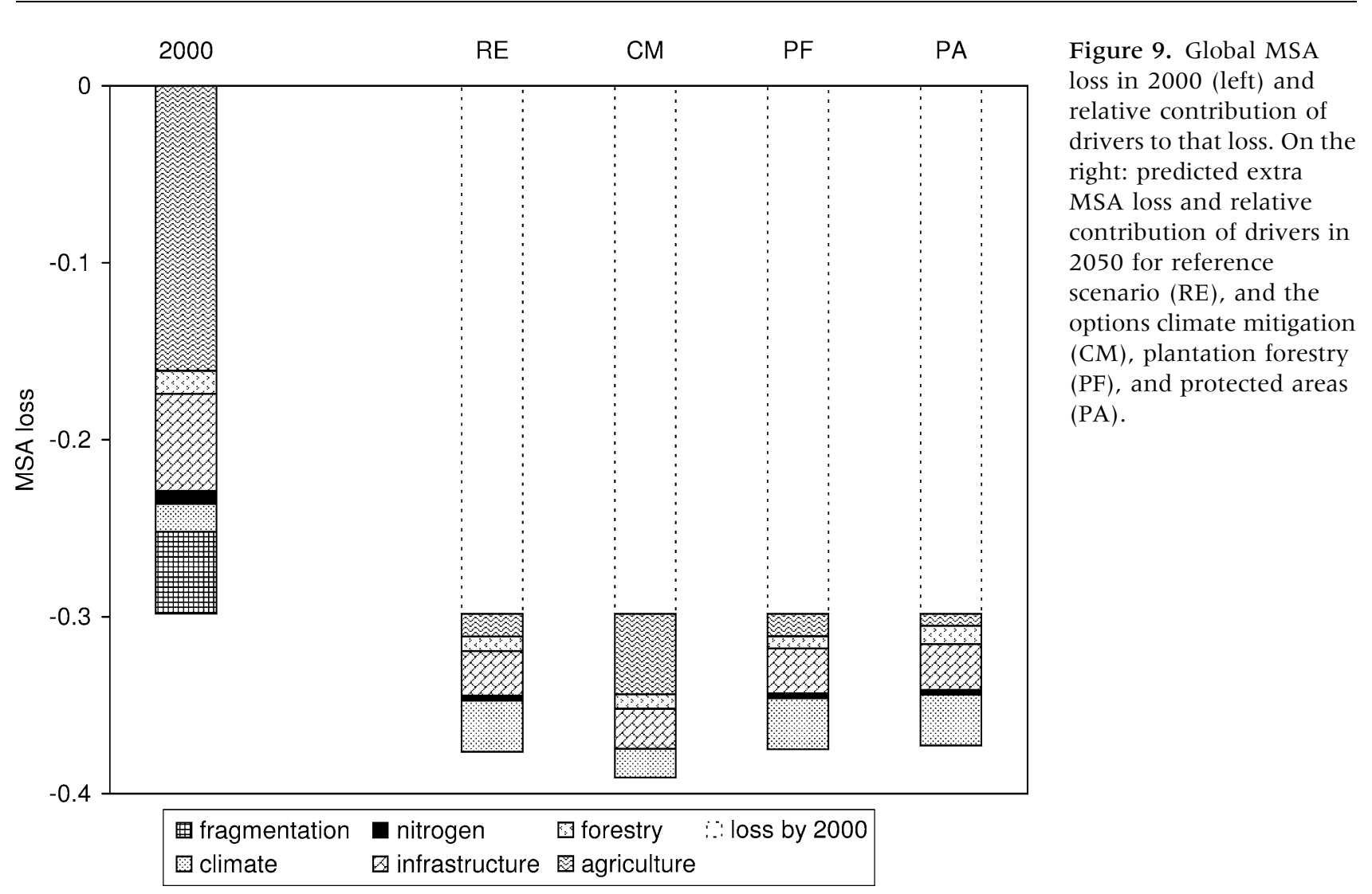

expected to increase, significantly, in the baseline scenario, whereas the impact of agriculture is expected to increase only slightly (Figure 9). Regions containing large areas of low-productive natural ecosystems, such as desert and tundra, show higher MSA values than regions already extensively used, for instance Europe and South-east Asia.

The effects of the different policy options are shown in Table 9 and Figure 9.

\section{Option: Climate Mitigation}

By 2050, the MSA gain $(+0.01)$ due to avoided climate change and reduced nitrogen deposition, does not compensate for the MSA loss $(-0.02)$ resulting from additional land use for bioenergy production, representing about $10 \%$ of the global agricultural area. The net MSA loss ranges from between -0.02 and +0.006 . Net losses are expected in regions where bioenergy crops are expected to be produced (North and South America, Russia, and North Asia); net MSA gain is expected in regions where reduced climate impacts are expected to occur (for example, North Africa). Bioenergy is assumed to be obtained from products mostly grown on abandoned agricultural land and converted natural grasslands.

\section{Option: Plantation Forestry}

Implementing the option in which the area for plantation forestry is increased, so that all wood produced in 2050 comes from sustainably managed plantations, leads initially to additional MSA loss due to increased land use for plantation establishment. When plantations gradually take over global production, the previously exploited (semi-)natural forests are left to recover. By 2050, the total worldwide MSA loss in the plantation-forestry option is slightly less $(0.001)$ than the loss resulting from ongoing exploitation of mostly (semi-)natural forests in the baseline scenario, ranging from a decreased MSA in Europe $(-0.006)$ to an increase of 0.008 in South and East Asia. As the (semi-)natural forests recover further, after 2050, the option will show better performance, in the longer term.

\section{Option: Protected Areas}

Effective conservation of $20 \%$ of each biome, for each major global region, will reduce global MSA loss by about 0.01 , ranging from 0.002 and 0.005 in North Africa and South America, respectively, where a large area is already formally protected, to 0.029 in Oceania and Japan. Effective conservation reduces land conversion, as well as hunting and 
small-scale human settlement, in areas that are still intact, and also enables restoration of partly degraded protected areas. Impacts of drivers, such as nitrogen deposition, fragmentation, and climate change, will, however, continue to affect protected areas.

MSA gains from effective conservation and restoration are partly compensated, following the shift of agricultural activities to adjacent areas, to fulfill human needs.

\section{Discussion ANd Conclusions}

The GLOBIO3 framework, linked to the integrated model IMAGE 2.4, allows the analysis of the biodiversity impacts in terms of MSA, of scenarios and policy options, at a global and regional level. The GLOBIO3 model framework is static rather than dynamic, and deterministic rather than stochastic. It is an operational tool to assess the combined effects of the most important drivers of biodiversity change.

Our conclusions confirm earlier studies and recent global assessment, such as the Millennium Ecosystem Assessment and the second Global Biodiversity Outlook (MA 2005; sCBD 2006). However, we need to consider a series of uncertainties inherent to GLOBIO3. Uncertainties relate to the cause-effect relationships, the drivers considered, the models estimating the drivers, the underlying data, and the indicators used. A formal uncertainty analysis including variances related to the MSA estimates and to the model outcomes of drivers is beyond the scope of this paper, and the topic for further study (for example, Hui and others 2008).

The cause-effect relationships are based on a limited set of published studies, which were interpreted in a uniform framework. Being a compilation of existing knowledge, the set of studies does not cover all biomes or represent all important species groups. For land use we performed an extensive meta-analysis and showed that MSA gradually decreases with land-use intensity increase. Our estimates are close to those found by Scholes and Biggs (2005) and Nichols and others (2007), although they used different indicators. Scholes and Biggs estimated the fractions of original species populations under a range of land-use types in southern Africa, based on expert knowledge. Nichols and others presented a meta-analysis on the effect of land conversion in tropical forests on dung beetles and used the Morisita Horn index of community similarity. Studies from currently heavily converted regions, such as Europe and East Asia, are underrepresented.
For infrastructure many of the studies included in the meta-analysis were performed in tundra and boreal forests, on either birds or mammals. Thus, effects on, for example, plants and insects, are underrepresented, yielding a bias to large animals. In contrast, effects of $\mathrm{N}$ deposition on MSA are mainly based on studies of plant species composition from temperate regions. Describing the effects of fragmentation, we chose to use data on the minimum area requirement of species. However, direct relationships of species abundances and patch size are also available (see Bender and others 1998). Although their conclusions are qualitatively similar to ours, a cause-effect relationship, based on the studies used by Bender and others may well differ from the MAR relationship. For climate, we here used generalizations from model studies on plant species in Europe (Bakkenes and others 2002) and biomes (Leemans and Eickhout 2004). The forecasted shifts of biomes are also used in the Millennium Ecosystem Assessment to mimic the effect of climate change on species (MA 2005). Currently, more studies are available on shifts of species using climate envelopes and forecasted climate change (for example, Peterson and others 2002; Thuiller and others 2006; Araújo and others 2006). Using these results the cause-effect relationship for climate may be improved, significantly. The possibilities of the use of paleo-ecological records to derive cause-effect relationships for climate change would be worth exploring.

Extensive meta-analyses, as used in GLOBIO3, depend on research papers that not only summarize field data, but also provide raw data on species occurrences. An alternative method for modeling impacts on biodiversity is to work with species distribution and abundance data. Long-term time series of species occurrences and abundances may help to validate the GLOBIO3 results (de Heer and others 2005). Models for species distribution can be developed by using different statistical techniques, combining the drivers behind species distributions, as suggested by Guisan and Zimmermann (2000) and further explored by Araújo and New (2006).

Some factors of possible major impact on biodiversity have not yet been included in the model. Sala and others (2000) considered the impact of biotic exchange and the direct impact of increased $\mathrm{CO}_{2}$ concentration in the atmosphere to be major factors, but, for these factors, cause-effect relationships have not yet been established in GLOBIO3, due to a lack of data. Other factors, such as fire incidence, extreme events, pollution (except atmospheric $\mathrm{N}$ deposition) have not been addressed, either. 
In addition to the cause-effect relationships, the GLOBIO3 model results depend largely on the quality of the data input. The area and spatial distribution of the different land-use classes is of particular importance. Different methods are used to estimate the areas of cropland, grazed land, forests, and other natural areas. Statistics available from the FAO (FAO 2006) and different satellite imagery sources (Bartholome and others 2004; Fritz and See 2008) indicate that uncertainty remains about the total area of agricultural land.

Similar uncertainties exist for the other drivers. Uncertainties in measurements and model forecasts for climate and $\mathrm{N}$ deposition are extensively documented in IPCC reports (IPCC 2007). The DCW infrastructure map is far from complete and differs, in detail, between regions. This incompleteness of the map makes it difficult to adequately distinguish between important roads and small roads. In addition forestry tracks, which have large impacts on biodiversity, are only sparsely represented in the DCW map. However, the DCW map is the only global map on infrastructure available and several other studies used the map to assess effects on biodiversity (Sanderson and others 2002; Wackernagel and others 2002).

The use of other indicators, as proposed in the core set by the Convention of Biological Diversity, may emphasize other aspects of biodiversity loss (UNEP 2004). Especially in the option of increasing protected areas, which are designed to protect specific species or ecosystems, a Red List index or indicator that is sensitive to uniqueness, will probably show stronger positive effects. By setting up a well-chosen network of protected areas, relatively large and intact ecosystems will be conserved, containing the majority of the species, including large-bodied, often slow-reproducing, and space-demanding species, such as large carnivores and herbivores, primates, and migratory animals. This will obviously improve the threatened' status of numerous species.

In spite of these uncertainties, our results show that MSA loss is expected to continue in every region of the world, but most severely in Sub-Saharan Africa and Europe. According to the baseline scenario, the rate of loss will not change in the coming 40-50 years, as a consequence of persistent economic and demographic development trends. These results are in line with the results from other global studies. Patterns of human disturbance, reflected by population density, degrees of human domination of ecosystems (McKee and others 2003; Cardillo and others 2004; Hannah and others 1994), patterns of the human footprint (Sanderson and others 2002), and patterns of human appropriation of net primary production (Imhoff and others 2004), all tend to match the MSA estimates of GLOBIO3. The estimated MSA loss (0.30) compared to pristine is similar to the results of Gaston and others (2003), who reported a range between 13 and $36 \%$ in reduced bird numbers. The Millennium Ecosystem Assessment estimates a global reduction of vascular plant biodiversity of between 13 and $19 \%$, between 1970 and 2050, whereas we estimated a reduction of between 7 and $9 \%$, from 2000 to 2050 . The similarity of the different analyses is not surprising, because all methods are dominated by factors related to land use and land conversion.

The OECD baseline scenario assumes that a considerable increase in agricultural productivity can be attained. The required agricultural area is up to $20 \%$ smaller than in the often used SRES scenarios of the Intergovernmental Panel on Climate Change (IPCC), and up to $28 \%$ smaller than in the Millennium Ecosystem Assessment (MA) scenarios (MA 2005). These scenarios, therefore, project an even greater loss of global MSA than does the OECD baseline scenario. Hence, it is unlikely that the CBD target of significantly reducing the rate of biodiversity loss for 2010 will be met, at the global level, assuming that MSA loss corresponds to overall biodiversity loss. Increasing agricultural productivity determines the differences between these scenarios and can, therefore, be a key factor in reducing the rate of MSA loss in the future. In addition we showed that some policy options may reduce the rate of loss, significantly. Production of wood in plantation forestry systems-where, in the long term, wood is produced on well managed plantations-has small but significant effects. An increase in protected areas in a well-chosen and effective network may also reduce MSA loss significantly, despite the trade-off with areas outside protected areas that will be converted, instead. As protected areas generally are focused on species rich areas a weighted version of MSA, using species numbers, may have given a more pronounced effect.

Climate change mitigation, including the largescale production of bio-energy crops, may have negative effects on MSA, with the positive effects of reducing climate change overruled by the negative effects of increased agriculture, even in a scenario that limits the scope to which natural ecosystems may be converted. Other climate change mitigation options, such as a successful agreement on reducing emissions from deforestation and forest degradation, may reduce future MSA loss, significantly. 
A concerted effort is essential, if the rate of loss is to be reduced in the coming 40-50 years. Optimal results can be obtained through a combination of options, including: maximum enhancement of agricultural productivity, reducing climate mitigation with little or very careful implementation of bio-energy, establishing plantation forestry on degraded lands, and realizing a major increase in effectively protected areas.

GLOBIO3 has proven to be very useful in global and regional biodiversity assessments, especially where scenarios or policy options were compared for their consequences. GLOBIO3 is successfully applied in regional and thematic assessments in the Himalaya and for deserts (Nellemann 2004; UNEP 2006). In recent global assessments, GLOBIO 3 was virtually the only available tool to assess possible consequences for biodiversity at that level (OECD 2008; UNEP 2007). Although GLOBIO3 is designed for global applications and, as such, can be considered part of the broader IMAGE 2.4 framework (MNP 2006 ) it is possible to use GLOBIO3 to examine the impact of drivers simulated by other models (for example, Verboom and others 2007). Furthermore the GLOBIO3 concept and cause-effect relationships are applicable for countries and regions where extensive data on biodiversity are absent.

\section{ACKNOWLEDGMENTS}

With thanks to Igor Lysenko at UNEP-WCMC for his work on the scenarios for global, protected areas. We thank Roland Bobbink of Utrecht University, Fleur Smout and Tonnie Tekelenburg of PBL, and Henk Simons of IUCN-NL for contributing to data collection and literature research. We thank two anonymous reviewers, Annemieke Righart of PBL and Jorn Scharlemann of UNEP-WCMC for improving the text.

\section{OPEN ACCESS}

This article is distributed under the terms of the Creative Commons Attribution Noncommercial License which permits any noncommercial use, distribution, and reproduction in any medium, provided the original author(s) and source are credited.

\section{REFERENCES}

Alcamo J, Leemans R, Kreileman E, Eds. 1998. Global change scenarios of the 21 st century. Results from the IMAGE 2.1 model. Oxford: Elsevier Science, p 296.

Allen CR, Pearlstine LG, Kitchens WM. 2001. Modeling viable populations in gap analyses. Biol Conserv 99:135-44.
Araújo MB, New M. 2006. Ensemble forecasting of species distributions. Trends Ecol Evol 22(1):42-7.

Araujo MB, Thuiller W, Pearson RG. 2006. Climate warming and the decline of amphibians and reptiles in Europe. J Biogeogr 33:1712-28.

Bakkenes M, Alkemade JRM, Ihle F, Leemans R, Latour JB. 2002. Assessing effects of forecasted climate change on the diversity and distribution of European higher plants for 2050 . Glob Chang Biol 8:390-407.

Bakkenes M, Eickhout B, Alkemade R. 2006. Impacts of different climate stabilisation scenarios on plant species in Europe. Glob Environ Change 16:19-28.

Bartholome E, Belward A, Beuchle R, Eva H, Fritz S, Hartley A, Mayaux P, Stibig H-J. 2004. Global land cover for the year 2000. European Commission, Joint Research Centre.

Bender DJ, Contreras TA, Fahrig L. 1998. Habitat loss and population decline: a meta-analysis of the patch size effect. Ecology 79:517-33.

Bobbink R, Ashmore M, Braun S, Fluckiger W, Van den Wyngaert IJJ. 2003. Empirical nitrogen critical loads fro natural and semi-natural ecosystems: 2002 update. In: Empirical critical loads fro nitrogen. Environmental Documentation No. 164. Swiss Agency for Environment, Forest and Landscape, Berne, Switzerland.

Bouwma IM, Jongman RHG, Butovsky RO. 2002. The indicative map of Pan-European ecological network-technical background document. In: ECNC Technical report series. Tilburg: ECNC.

Bouwman AF, Van Vuuren DP, Derwent RG, Posch M. 2002. A global analysis of acidification and eutrophication of terrestrial ecosystems. Water Air Soil Pollut 141:349-82.

Brown C. 2000. The global outlook for future wood supply from forest plantations. In: Working Paper No GFPOS/WP/03. Rome: FAO, p 141.

Cardillo M, Purvis A, Sechrest W, Gittleman JL, Bielby J, Mace GM. 2004. Human population density and extinction risk in the world's carnivores. PLoS Biol 2:909-14.

de Heer M, Kapos V, Ten Brink BJE. 2005. Biodiversity trends in Europe: development and testing of a species trend indicator for evaluating progress towards the 2010 target. Phil Trans R Soc B 360:297-308

Dixon J, Gulliver A, Gibbon D. 2001. Farming systems and poverty. FAO and World bank: Rome and Washington DC.

DMA. 1992. Digital chart of the world. Fairfax, Virginia: Defense Mapping Agency.

Duellman WE, Ed. 1999. Patterns of distribution of amphibians: a global perspective. Baltimore, USA: John Hopkins University Press.

Faith DP, Ferrier S, Williams KJ. 2008. Getting biodiversity intactness indices right: ensuring that 'biodiversity' reflects 'diversity'. Glob Chang Biol 14:207-21.

FAO. 2001. Global forest resources assessment 2000. Main Report. FAO Forestry Paper 140, Rome: FAO.

FAO. 2006. Global forest resources assessment 2005. Progress towards sustainable forest management. FAO Forestry Paper. Rome: FAO, p 320.

Fritz S, See L. 2008. Identifying and quantifying uncertainty and spatial disagreement in the comparison of Global Land Cover for different applications. Glob Chang Biol. Available from: http://www.blackwell-synergy.com/doi/abs/10.1111/j.13652486.2007.01519.x (online early). 
Gaston KJ, Blackburn TM, Klein Goldewijk K. 2003. Habitat conversion and global avian biodiversity loss. Proc R Soc Lond B 270:1293-1300.

Guisan A, Zimmermann NE. 2000. Predictive habitat distribution models in ecology. Ecol Modell 135:147-86.

Hannah L, Lohse D, Hutchinson C, Carr JL, Lankerani A. 1994. A preliminary Inventory of Human Disturbance of world ecosystems. Ambio 23:246-50.

Hui D, Biggs R, Scholes RJ, Jackson RB. 2008. Measuring uncertainty in estimates of biodiversity loss: the example of biodiversity intactness variance. Biol Conserv 141:1091-4.

IMAGE-team. 2001. The IMAGE 2.2 implementation of the SRES scenarios. CD-ROM publication 481508018. Bilthoven, The Netherlands: National Institute for Public Health and the Environment.

Imhoff ML, Bounoua L, Ricketts T, Loucks C, Hariss R, Lawrence WT. 2004. Global patterns in human consumption of the net primary production. Nature 429:870-3.

Insightful Corp. 2005. S-PLUS enterprise developer version 7.0.6 for Microsoft Windows. Insightful Corp.

IPCC. 2007. Climate change 2007-the physical science basis: contribution of working group 1 to the fourth assessment report of the IPCC. UK: Cambridge University Press.

IUCN. 2004. The Durban action plan. www.iucn.org/themes/ wcpa/wpc2003/english/outputs/durban/daplan.html. Revised March 2004. Accessed 8 April 2008.

Leemans R, Eickhout B. 2004. Another reason for concern: regional and global impact of ecosystems for different levels of climate change. Glob Environ Change A 14:219-28.

Loh J, Green RE, Ricketts T, Lamoreux J, Jenkins M, Kapos V, Randers J. 2005. The Living Plant Index: using species population time series to track trends in biodiversity. Phil Trans $\mathrm{R}$ Soc B 360:289-295.

MA. 2003. Ecosystems and human well-being, a framework for assessment. Washington, Covelo, London: Island Press.

MA. 2005. Millennium ecosystem assessment. Ecosystems and human well-being: scenarios2 Washington, DC: Island Press.

Majer JD, Beeston G. 1996. The Biodiversity Integrity Index: an illustration using ants in Western Australia. Conserv Biol 10:65-73.

McKee JK, Sciulli PW, Fooce CD, Waite TA. 2003. Forecasting global biodiversity threats associated with human population growth. Biol Conserv 115:161-4.

Metz B, Van Vuuren DP. 2006. How, and at what costs, can lowlevel stabilsation be achieved?-An overview. Avoiding dangerous climate change. Cambridge: Cambridge University Press.

MNP. 2006. Integrated modelling of global environmental change. An overview of IMAGE 2.4. Bilthoven, the Netherlands: Netherlands Environmental Assessment Agency (MNP).

Myers N, Mittermeier RA, Mittermeier CG, da Fonseca GA, Kent J. 2000. Biodiversity hotspots for conservation priorities. Nature 403(6772):853-8.

Nakicenovic N, Alcamo J, Davis G, De Vries B, Fenhann J, Gaffin S, Gregory K, Grübler A, Jung TY, Kram T, Rovere EEl, Michaelis L, Mori S, Morita T, Pepper W, Pitcher H, Price L, Riahi K, Roehrl A, Rogner H, Sankovski A, Schlesinger M, Shukla P, Smith S, Swart R, Van Rooyen S, Victor N, Dadi Z. 2000. Special report on emissions scenarios. Cambridge: Cambridge University Press.
Nellemann C, Ed. 2004. The fall of the water. Norway: United Nations Environmental Programme-GRID Arendal.

Nichols E, Larsen T, Spector S, Davis AL, Escobar F, Favila M, Vulinec K, The Scarabaeinae Research Network. 2007. Global dung beetle response to tropical forest modification and fragmentation: a quantitative literature review and metaanalysis. Biol Conserv 137:1-19.

OECD. 2008. Environmental outlook to 2030. Paris, France: Organisation for Economic Cooperation and Development.

Olson DM, Dinerstein E. 1998. The global 200: a representation approach to conserving the earth's most biologically valuable ecoregions. Conserv Biol 12(3):502-15.

Olson DM, Dinerstein E, Wikramanayake ED, Burgess ND, Powell GVN, Underwood EC, D'Amico JA, Itoua I, Strand HE, Morrison JC, Loucks CJ, Allnutt TF, Ricketts TH, Kura Y, Lamoreux JF, Wettengel WW, Hedao P, Kassem KR. 2001. Terrestrial ecoregions of the world: a new map of life on earth. Bioscience 51(11):933-8.

Osenberg CW, Sarnelle O, Cooper SD, Holt RD. 1999. Resolving ecological questions through meta-analysis: goals, metrics and models. Ecology 80:1105-17.

Peterson AT, Ortega Huerrta MA, Bartley J, Sanchez Cordero V, Buddemeier RH, Stockwell DRB. 2002. Future projections for Mexican faunas under global climate change scenarios. Nature 416:626-9.

Petit S, Firbank L, Wytt B, Howard D. 2001. MIRABEL: models for integrated review and assessment of biodiversity in European landscapes. Ambio 30:81-8.

Pinheiro JC, Bates DM. 2000. Mixed-effects models in S and SPLUS. New York: Springer-Verlag.

Prentice C, Cramer W, Harrison SP, Leemans R, Monserud RA, Solomon AM. 1992. A global biome model based on plant physiology and dominance, soil properties and climate. J Biogeogr 19:117-34.

Ricketts TH, Dinerstein E, Boucher T, Brooks TM, Butchart SH, Hoffmann M, Lamoreux JF, Morrison J, Parr M, Pilgrim JD, Rodrigues AS, Sechrest W, Wallace GE, Berlin K, Bielby J, Burgess ND, Church DR, Cox N, Knox D, Loucks C, Luck GW, Master LL, Moore R, Naidoo R, Ridgely R, Schatz GE, Shire G, Strand H, Wettengel W, Wikramanayake E. 2005. Pinpointing and preventing imminent extinctions. Proc Natl Acad Sci USA 102(51):18497-501.

Sala OE, Chapin FS III, Armesto JJ, Berlow E, Bloomfield J, Dirzo R, Huber-Samwald E, Huenneke KF, Jackson RB, Kinzig A, Leemans R, Lodge DM, Mooney HA, Oesterheld M, Poff NL, Sykes MT, Walker BH, Walker M, Wall DH. 2000. Global biodiversity scenarios for the year 2100. Science 287:1770-74.

Sanderson EW, Jaiteh M, Levy MA, Redford KH, Wannebo AV, Woolmer G. 2002. The human footprint and the last of the wild. Bioscience 52:891-904.

sCBD. 2006. Global biodiversity outlook 2. Montreal: Secretariat of the Convention on Biological Diversity. p $81+$ vii.

sCBD and MNP. 2007. Cross-roads of life on earth-exploring means to meet the 2010 Biodiversity target. Solution-oriented scenarios for global biodiversity outlook 2 . Technical Series no 31. Montreal: Secretariat of the Convention on Biological Diversity. p 90.

Scholes RJ, Biggs R. 2005. A biodiversity intactness index. Nature 434:45-9.

Stattersfield AJ, Crosby MJ, Long AJ, Wege DC. 1998. Endemic bird areas of the world. Cambridge, UK: Birdlife International. 
Thuiller W, Broennimann O, Hughes G, Alkemade JRM, Midgley GF, Corsi F. 2006. Vulnerability of African mammals to anthropogenic climate change under conservative land transformation assumptions. Glob Chang Biol 12:424-40.

UNEP. 2001. GLOBIO. Global methodology for mapping human impacts on the biosphere. Report UNEP/DEWA/TR 25. Nairobi: United Nations Environmental Programme.

UNEP. 2002a. Decision VI/26: strategic plan for the convention on biological diversity. In: Seventh conference of the parties to the convention on biological diversity, The Hague, 2002.

UNEP. 2002b. Global environment outlook 3. London: Earthscan Publications Ltd.

UNEP. 2004. Decisions adopted by the conference of the parties to the convention on biological diversity at its seventh meeting (UNEP/CBD/COP/7/21/Part 2), decision VII/30 (CBD 2004). http://www.biodiv.org/decisions/.

UNEP. 2006. Global deserts outlook. Division of early warning and assessment. Nairobi, Kenya: United Nations Environmental Programme.

UNEP. 2007. Global environmental outlook 4. Environment for development. Nairobi, Kenya: United Nations Environmental Programme.
UNEP/RIVM. 2004. The GEO-3 scenarios 2002-2032: quantification and analysis of environmental impacts. Report UNEP/ DEWA/RS03-04; RIVM 402001022. Division of early warning and assessment. DEWA-UNEP./. Nairobi, Kenya; Bilthoven, The Netherlands: National Institute for Public Health and the Environment. RIVM, p 216.

UNEP/WCMC. 2005. World database on protected areas version 01/11/2005. http://www.unep-wcmc.org/wdpa.

Venables WN, Ripley BD. 1999. Modern applied statistics with SPLUS. 3rd edn. New York: Springer-Verlag.

Verboom J, Alkemade R, Klijn J, Metzger MJ, Reijnen R. 2007. Combining biodiversity modeling with political and economical development scenarios for 25 countries. Ecol Econ 62:267-76.

Wackernagel M, Schulz NB, Deumling D, Callejas Linares A, Jenkins M, Kapos V, Monfreda C, Loh J, Myers N, Norgaard R, Randers J. 2002. Tracking the ecological overshoot of the human economy. PNAS 99:9266-71.

Woodroffe R, Ginsberg JR. 1998. Edge effects and the extinction of populations inside protected areas. Science 280:2126-8. 